\title{
Therapeutic Itinerary of Patients Followed for Connectivitis in the Internal Medicine Department of the CNHU-HKM of Cotonou (Benin)
}

\author{
Angèle Azon-Kouanou*, Kouessi Anthelme Agbodande, Eugénie Dansou, \\ Mahoutin Semassa Ghislain Missiho, Yves Morel Sokadjo, Armand Finagnon Wanvoegbe, \\ Janvier Kitumaini Kondoli, Richard Oba, Roberto Dossou Tores Kouassi Prudencio, \\ Djimon Marcel Zannou, Fabien Houngbé
}

\author{
Internal Medicine and Medical Oncology Department, National Teaching Hospital (NTH), Hubert Koudougou Maga (HKM), \\ Cotonou, Bénin \\ Email: *angele.azonkouanou@gmail.com
}

\begin{abstract}
How to cite this paper: Azon-Kouanou, A., Agbodande, K.A., Dansou, E., Missiho, M.S.G., Sokadjo, Y.M., Wanvoegbe, A.F., Kondoli, J.K., Oba, R., Prudencio, R.D.T.K., Zannou, D.M. and Houngbé, F. (2021) Therapeutic Itinerary of Patients Followed for Connectivitis in the Internal Medicine Department of the CNHU-HKM of Cotonou (Benin). Open Journal of Internal Medicine, 11, 73-80.
\end{abstract}

https://doi.org/10.4236/ojim.2021.112006

Received: March 23, 2021

Accepted: May 11, 2021

Published: May 14, 2021

Copyright $\odot 2021$ by author(s) and Scientific Research Publishing Inc. This work is licensed under the Creative Commons Attribution International License (CC BY 4.0).

http://creativecommons.org/licenses/by/4.0/

(c) (i) Open Access

\begin{abstract}
Introduction: In black Africa, connectivites have been for a long time a source of diagnostic erraticity because of their clinical polymorphism. This study aims to determine the therapeutic itinerary of patients followed for connectivitis in the Internal Medicine Department of the CNHU HKM of Cotonou. Methodology: This is a cross-sectional study that included patients followed for connectivitis in the HKM-Cotonou Internal Medicine Department from January 2010 to October 2018. Results: Out of 3600 patients hospitalized in the study period, 21 had connectivitis, i.e. a hospital frequency of $0.58 \%$. Of the 21 patients collected, 18 met the inclusion criteria. The mean age was $40( \pm 11)$ years old and the youngest was of 21 and the oldest 58 . The sex ratio was 17.9. The "Fon" ethnic group was the most represented $(33.3 \%)$ and $15(83.3 \%)$ subjects were Christians. Systemic lupus erythematosus was the most frequent connectivitis (55.6\%). The average time of consultation was 38 months. Witchcraft was the most incriminating cause (78\%). Ten (55.5\%) patients had resorted to self-medication as their first choice of treatment, 5 (27.8\%) to traditional medicine treatment and 3 (16.7\%) to prayer for healing. The reasons for the first choice of treatment were satisfaction (44.4\%), financial problems (27.8\%), trivialization of the disease (16.7\%), and advice from family and friends (11.1\%). The consultation at the CNHU followed a referral from a first contact health structure $(61 \%)$ or an initiative of the patient (27.8\%). Conclusion: Connectivitis is a source of diagnostic error in our con-
\end{abstract}


text. Awareness must be raised among patients for an early consultation at the first symptoms.

\section{Keywords}

Connectivitis, Therapeutic Itinerary, CNHU-HKM Cotonou

\section{Introduction}

Systemic diseases are a heterogeneous group of diffuse autoimmune and/or autoinflammatory diseases and syndromes, usually involving several systems [1]. They affect about $5 \%$ of the world population [2]. The causes are generally unknown. Their occurrence is considered as the result of the interaction between environmental and genetic susceptibility factors, that taken in isolation, are neither necessary nor sufficient to induce such diseases [3]. Among the systemic diseases, connectivitis or collagenosis was initially referred to a group of disorders with a common denominator of anatomopathological changes in connective tissue [4]. This term is still in use despite the considerable evolution of pathophysiological concepts that no longer emphasize collagenous tissue abnormalities and usually focuses on systemic lupus erythematosus (SLE), inflammatory myopathies, systemic scleroderma, primary Gougerot-Sjögren's syndrome and mixed connectivitis [4]. Indeed, the connectivitis is non-organ-specific autoimmune disease. They are responsible for multivisceral disorders and have diverse presentations that make their diagnosis difficult. The criteria used for their diagnosis are based on symptomatic groupings and are the result of a statistical analysis established most often from a recruitment of patients with rheumatological diseases. Some patients meet the criteria for several connectivitis: this is known as an overlap syndrome. Others have anti-RNP antibodies and are classified as having "mixed connectivitis", with elements of systemic lupus, scleroderma, and myositis but not meeting the criteria for classification of connectivitis. Finally, some patients who have only a few manifestations may be classified as "undifferentiated connectivitis" [4]

These chronic diseases, can disrupt the quality of life of the patient with the possibility of a psychosocial impact [5]. Worldwide, very few studies have been carried out on connectivitis, and each connectivity has been studied separately.

In black Africa, these conditions are a source of diagnostic erraticism because of their clinical polymorphism. In recent years, several publications have highlighted the low hospital frequency of connectivitis in the cities of the countries of the sub-region: $0.14 \%$ in Dakar in internal medicine [6], $0.14 \%$ and $0.8 \%$ respectively in dermatology and rheumatology in Lomé [7], and 2.29\% in internal medicine and dermatology in Ouagadougou [5]. In Benin, the Agbodande study found a hospital frequency of $0.8 \%$ in internal medicine in Cotonou [8].

However, these studies did not look at the patients' therapeutic itinerary. Hence, the current study has as the main goal to study the therapeutic course of patients 
treated for connectivitis tissue disease in the internal medicine department of the CNHU-HKM in Cotonou.

\section{Patients and Methods}

Our study occurred in the university clinic of Internal Medicine of the CNHUHKM of Cotonou.

It was a cross-sectional, descriptive, and analytical study.

Adult patients who were followed in the department from January 2010 to October 2018 for connectivitis and gave their informed consent were included.

Actually, we did not include, dead eligible patients or unable to answer the questions.

The diagnosis of connectivitis was made by hospital practitioners on the basis of diagnostic criteria specific to each connectivitis: ACR/EULAR for Systemic Lupus Erythematosus, Kahn's classification for mixed connectivitis, International Consensus on the Update of Criteria for Antiphospholipid Syndromes, ACR/ EULAR for systemic scleroderma. For each patient, anthropological (age, sex, ethnicity, religion), sociological (average consultation time, choice of first therapeutic recourse, reasons for choice, financial support for care), and clinical (medical history, type of connective tissue disease, complications) variables were studied.

To study the influence of choice on prognosis, two subgroups were formed: A $=$ connectivitis without complications and $\mathrm{B}=$ connectivitis with complications.

Data collection was done using a survey form. Data analysis and processing were performed by EPI DATA.3.1. For comparisons, the Fischer Chi-square test was used, and a $p<0.05$ indicated a significant difference.

\section{Results}

Among three thousand and six hundred patients that were hospitalized during the study period, 21 had connectivitis. In other words, we got a hospital frequency of $0.58 \%$. Furthermore, over the 21 patients who were selected, 18 met the inclusion criteria.

\subsection{Profile of the Patients}

The mean age was $40( \pm 11)$ years old and the youngest was 21 and the oldest was 58. 94.4\% of patients were female and "Fon" ethnic group was the most represented (33.3\%) followed by "Goun" (16.7\%) and "Mina" (11.1\%) ethnic groups. Let's note that $15(83.3 \%)$ patients were Christians. The medical history of our patient was dominated by spontaneous miscarriage (27.8\%). Arterial hypertension and stillbirths were also found in the same proportions (16.7\%). Systemic lupus erythematosus (SLE) was the most frequent connectivitis $(55.6 \%)$. The sociodemographic characteristics of the study population are presented in Table 1, and the distribution of the different connectivitis in Table 2. 
Table 1. Socio-demographic characteristics.

\begin{tabular}{|c|c|c|}
\hline & Frequency & $(\%)$ \\
\hline \multicolumn{3}{|l|}{ Gender } \\
\hline Man & 1 & 5.6 \\
\hline Women & 17 & 94.4 \\
\hline \multicolumn{3}{|l|}{ Ethnic Group } \\
\hline Fon and apparent & 16 & 88.9 \\
\hline Nago Yoruba & 2 & 11.1 \\
\hline \multicolumn{3}{|l|}{ Religion } \\
\hline No religion & 1 & 5.6 \\
\hline Muslim & 2 & 11.1 \\
\hline Christian & 15 & 83.3 \\
\hline \multicolumn{3}{|l|}{ Education } \\
\hline None & 3 & 16.7 \\
\hline Elementary School & 1 & 5.6 \\
\hline High School & 6 & 33.3 \\
\hline Graduate School & 8 & 44.4 \\
\hline \multicolumn{3}{|l|}{ Matrimonial situation } \\
\hline Single & 9 & 50.0 \\
\hline Married & 8 & 44.4 \\
\hline Divorced & 1 & 5.6 \\
\hline \multicolumn{3}{|l|}{ Profession } \\
\hline Employee & 8 & 44.4 \\
\hline Non-employee & 10 & 55.6 \\
\hline \multicolumn{3}{|l|}{ Residence } \\
\hline Cotonou & 15 & 83.3 \\
\hline Outside Cotonou & 3 & 16.7 \\
\hline
\end{tabular}

Table 2. Repair of different connectivitis.

\begin{tabular}{ccc}
\hline & Frequency & $\%$ \\
\hline SYSTEMIC LUPUS ERYTHEMATOSUS & 10 & 55.6 \\
MIXED CONNECTIVITIS & 5 & 27.7 \\
ANTI PHOSPHOLIPID SYNDROME & 1 & 5.6 \\
SCLERODERMIA & 2 & 11.1 \\
Total & 18 & 100.0 \\
\hline
\end{tabular}

\subsection{Therapeutic Itinerary of the Study Population}

The average time to consultation was 38 months. The most common cause was 
witchcraft in $78 \%$ of the cases. Self-medication was the first choice $(55.5 \%)$ of treatment. In addition, treatment by traditional medicine $(27.8 \%)$ and prayer for healing $(16.7 \%)$ were less frequent. The reasons for the first choice of treatment were about satisfaction (44.4\%), financial problems (27.8\%), trivialization of the disease (16.7\%), and advice from family and friends (11.1\%). The consultation at the CNHU followed either a referral from a first contact health structure (61\%), the patient's private initiative (27.8\%), or the advice of a third person (5.6\%). Financial responsibility for the care was assumed in $61.1 \%$ of cases by the patients themselves, and sometimes by their parents $(22.2 \%)$ or spouses $(16.1 \%)$.

\subsection{Factors Associated with the Occurrence of Complications}

Five (27.8\%) patients had complications, including pulmonary hypertension (2 cases), diffuse interstitial lung disease (1 case), lupus nephropathy (1 case) and pulmonary embolism (1 case). Patients with arterial hypertension as a comorbidity $(\mathrm{p}=0.044)$ and those with a Christian religion $(\mathrm{p}=0.002)$ presented more complications. There was no significant association with other risk factors. The factors associated with the occurrence of complications have been summarized in Table 3.

Table 3. Summary of factors associated with the occurrence of complications.

\begin{tabular}{|c|c|c|c|c|}
\hline \multirow{2}{*}{\multicolumn{2}{|c|}{ Variables }} & \multicolumn{2}{|c|}{ Complications } & \multirow{2}{*}{$\mathrm{p}$-value } \\
\hline & & Yes & No & \\
\hline \multirow{3}{*}{ Sex } & Male & 1 & 0 & 0.27 \\
\hline & & & & \\
\hline & Female & 4 & 13 & \\
\hline \multirow{2}{*}{ Profession } & Salaried employee & 2 & 6 & 0.61 \\
\hline & Non salaried & 3 & 7 & \\
\hline \multirow{3}{*}{ Religion } & Christians & 3 & 12 & 0.002 \\
\hline & Muslims & 2 & 0 & \\
\hline & Without religion & 0 & 1 & \\
\hline \multirow{5}{*}{ Medical histort } & HBP & 3 & 0 & 0.044 \\
\hline & Miscarriage & 1 & 4 & 0.64 \\
\hline & Stillbirth & 1 & 2 & 0.81 \\
\hline & HIV & 0 & 1 & 0.52 \\
\hline & PR & 1 & 1 & 0.45 \\
\hline \multirow{3}{*}{$1^{\mathrm{er}}$ remedy } & Automedication & 4 & 9 & 0.64 \\
\hline & Phytotherapy & 3 & 6 & 0.59 \\
\hline & Prayer & 1 & 4 & 0.64 \\
\hline \multirow{3}{*}{ Reference way giver } & Health institution & 3 & 8 & 0.76 \\
\hline & personnal decision & 0 & 1 & \\
\hline & Third party & 2 & 3 & \\
\hline
\end{tabular}




\section{Discussion}

In our study, the hospital frequency of connectivitis was $0.58 \%$. It is higher than those found in Dakar (internal medicine) and Lomé (dermatology) that were, respectively, $0.14 \%$ and $0.2 \%$ [6] [7]. On the other hand, it is lower than the one that was found in rheumatology in Lomé and Ouagadougou, that were, respectively $0.8 \%$ and $2.29 \%$ [5] [7]. These hospital frequencies are low and it reflects the under-diagnosis of connectivitis in our country. The differences observed could be explained by the small size of our sample. They can also be explained by the fact that rheumatology is a specialty where osteoarticular manifestations of connectivitis are more frequently encountered.

The mean age of the patients was $40( \pm 11)$ years old with a minimum of 21 and a maximum of 58 years. This result was found in other works from the sub-region with an average age of $41.2( \pm 11.97)$ years old in Burkina Faso [5] and 43.7 in Senegal [6]. Connectivitis occurs in young people.

In our series, the majority of patients were women (94.4\%), in particular young sexually active women. The same observation is made by the majority of studies on connectivitis. This can be explained by the role of hormones in the occurrence of diseases of the system. Estrogens are thought to increase the secretion of prolactin and growth hormones, which in turn may play a role in the proliferation of $\mathrm{T}$ and B lymphocytes [9]. On the other hand, androgens seem to have inhibitory effects on the immune response by mechanisms acting directly on cells of the immune system or on some target organs [10].

In our study, SLE was the main connective tissue disease found (55.6\%), followed by mixed connective tissue disease (27.7\%). This predominance of SLE is not always found. Although our results are comparable to those of Missounga [11] and Aubry-Rozier [12], the studies by Mijiyawa and Leye found scleroderma and rheumatoid arthritis respectively in the first place [6] [7]. This may be explained by the fact that Mijiyawa's study was conducted in dermatology. However, Leye's study was conducted in an internal medicine department.

The mean time to consultation for the 18 patients was 38 months, with a minimum of 6 and a maximum of 180 months. This delay is much longer than that found in Gabon, 16.5 months in a study of only 7 patients [11].

The majority of patients had self-medication as their first therapeutic remedy (55.5\%). The main reasons for this therapeutic choice were satisfaction (44.4\%) followed by financial problems (27.8\%). Ouendo's study on the therapeutic itinerary of patients in Benin concurs. More than half of the patients in the study had self-medication as their first therapeutic remedy [13]. According to the author, traditional therapeutic recipes and the proliferation of informal sellers and prescribers of medicines favored this practice.

The consultation at the CNHU was mainly the result of a referral from a first contact health facility (61\%). A patient's initiative or advice from a third party was the origin of the consultation in $27.8 \%$ and $5.6 \%$ of cases respectively. These results highlight the role of first contact health facilities in the Beninese health 
system. Awareness must be raised among patients and primary care physicians for early consultation and referral to an appropriate health center at the first sign of symptoms. Azon-Kouanou's study on general practitioners' knowledge of SLE in Cotonou (Benin), noted the lack of knowledge of the disease among primary care physicians [14].

The first people involved in the financial management of the disease were the patients themselves (61.1\%). This attitude contrasts with the high number of non-salaried patients and the absence of health insurance for all. This situation makes difficult to follow up the patients properly and would favour the occurrence of complications.

We got 5 (27.8\%) patients with complications during the disease, including 2 cases of pulmonary hypertension, 1 case of pulmonary embolism, 1 case of lupus nephropathy and 1 case of diffuse interstitial lung disease. These complications are among those frequently encountered in connectivitis. The factors associated with the occurrence of these complications were hypertension $(\mathrm{p}=0.044)$ and Christian religion $(\mathrm{p}=0.002)$. If HTA can be a cause of chronic inflammation that could explain the association, the Christian religion as an associated factor does not have an objective explanation. We believe that this association found would be related to the selection bias of the study. Indeed, 15 out of the 18 patients included were Christian. However, a study on the impact of religious belief on the patients' therapeutic itinerary would help to better understand this association.

\section{Limitations of the Study}

The main limitation of this study is the sample size. A multi-center study with a larger sample size will allow for a more in-depth study.

\section{Conclusion}

Connectivites are multifaceted chronic inflammatory diseases whose frequency seems low in Africa. This observation is the consequence of an under diagnosis linked not only to the lack of knowledge of the pathology by primary care physicians, but also to the limitation of the technical platform. It justifies that patients are seen with complications in one-third of the cases. The worry in this context is the early onset of complications.

\section{Conflicts of Interest}

The authors declare no conflicts of interest regarding the publication of this paper.

\section{References}

[1] Kane, B.S., Ndongo, S., Ndiaye, A.A., Djiba, B., Niasse, M., Diack, N. and Pouye, A. (2016) Systemic Diseases in Internal Medicine "African Context": Epidemiological Aspects and Classification. La Revue de Médecine Interne, 37, A37. https://doi.org/10.1016/j.revmed.2016.04.237 
[2] Bonnotte, B. (2004) Pathogenic Mechanisms of Autoimmune Diseases. La Revue de Médecine Interne, 25, 648-658. https://doi.org/10.1016/j.revmed.2004.02.003

[3] Subra, J.F. (2004) Silica and Auto-Immunity. Revue Française des Laboratoires, 2004, 23-25. https://doi.org/10.1016/S0338-9898(04)90090-X

[4] Mouthon, L. (2018) Epidemiology, Classification of Connectivites. JMV-Journal de Médecine Vasculaire, 43, 74. https://doi.org/10.1016/j.jdmv.2017.12.004

[5] Ouédraogo, D.D., Korsaga-Somé, N., Zabsonné Tiendrébéogo, J., Tiéno, H., Kaboré, H., Niamba, P. and Drabo, J. (2014) Connective Tissue Diseases in Hospital Practice in Ouagadougou (Burkina Faso). Médecine et Santé tropicales, 24, 271-274. https://doi.org/10.1684/mst.2014.0348

[6] Lèye, Y.M., Ndiaye, N., Diack, N.D., Ndour, M.A., Fall, B.C., Waly, K.A. and Abdoulaye, L.E.Y.E. (2017) Epidemiological and Diagnostic Aspects of Connectivitis in the Internal Medicine Department of the CHUN of Pikine: Analysis of 287 Observations. Revue Africaine de Médecine Interne, 4, 22-25.

[7] Mijiyawa, M., Amanga, K., Oniankitan, O.I., Pitche, P. and Tchangai-Walla, K. (1999) Connectivitis in Hospital Consultation in Lomé (Togo). La Revue de médecine interne, 20, 13-17. https://doi.org/10.1016/S0248-8663(99)83004-5

[8] Agbodande, K.A., Prudencio R.D.T., Azon-Kouanou A., Wanvoegbe, A., Cossou-Gbeto, C., Zannou, D.M. and Houngbe, F. (2019) Overview of Connectivitis in Internal Medicine at the Centre National Hospitalier et Universitaire-Hubert Koutoukou Maga in Cotonou. Journal de la Société de Biologie Clinique du Bénin, 31, 66-70.

[9] Huck, Sand Zouali, M. (1996) Gender-Related Factors and Autoimmune Diseases. Annales de PInstitut Pasteur/Actualités, 7,143-146. https://doi.org/10.1016/S0924-4204(97)85209-2

[10] Spector, T.D., Ollier, W., Perry, L.A., Silman, A.J., Thompson, P.W. and Edwards, A. (1989) Free and Serum Testosterone Levels in 276 Males: A Comparative Study of Rheumatoid Arthritis, Ankylosing Spondylitis and Healthy Controls. Clinical rheumatology, 8, 37-41. https://doi.org/10.1007/BF02031066

[11] Missounga, L., Ba, J.I., Ondo, I.R.N.N., Madjinou, M.I.C.N., Malekou, D., Mouloungui, E.G.M. and Kombila, M. (2017) Mixed Connectivity: Prevalence and Clinical Characteristics in Black Africans, Study of 7 Cases in Gabon and Review of the Literature. The Pan African Medical Journal, 27, Article 162. https://doi.org/10.11604/pamj.2017.27.162.12572

[12] Aubry-Rozier, B. and Fabreguet, I. (2013) Connective Tissue Diseases: News in Therapy, Role of Biologics Agents. Revue Medicale Suisse, 9, 556-558.

[13] Ouendo, E.M., Makoutodé, M., Paraiso, M.N., Wilmet-Dramaix, M. and Dujardin, B. (2005) Therapeutic Itinerary of Indigent Patients in Benin (Poverty and Health Care). Tropical Medicine \& International Health, 10, 179-186. https://doi.org/10.1111/j.1365-3156.2004.01371.x

[14] Azon-Kouanou, A., Aboué, N.C.A., Missiho, M.S.G., Dansou, E., Sokadjo, Y.M., Agbodande, K.A., Wanvoegbe, A.F., Zannou, D.M. and Houngbé, F. (2020) Knowledge of General Practitioners in Cotonou about Systemic Lupus Erythematosus. Open Journal of Internal Medicine, 10, 311-320. https://doi.org/10.4236/ojim.2020.104032 